The article deals with analysis of the methodical guidelines, under lying the review of the aspect, and proposes consistent use of various tasks, enabling international students to expand their vocabulary and facilitating their understanding of semantic and derivational processes, peculiar to scientific-technical type of the Ukrainian language scientific style. Consequently, the research allowed to draw the following conclusions: there should be a certain distinction in the study of the word formation in language classes of foreign classroom, aimed at technical and humanities education. Collected and reviewed material will contribute to refinement of educational process of learning Ukrainian by foreign citizens,studying in technological institutions of higher education. The findings of the research can serve as a basis for generalization of basic word-formation means, featuring scientific and technical genre of the Ukrainian language scientific style.

Key words: Ukrainian as a foreign language, morphemic structure, word formation, methodology of teaching, minimized word-formation nest, description of terms denoting lasting process.

Статтю отримано 18.04.2021 p.

DOI: $10.18524 / 2307-4558.2021 .35 .237861$

УДК 811.161.2’243:378.147

ТРУБА Ганна Миколаївна,

кандидат філологічних наук, доцент кафедри прикладної лінгвістики Одеського національного університету імені I. І. Мечникова; Французький бульвар, 24/26, м. Одеса, 65058, Україна; тел.: + 380632366706 ;

e-mail: 3182009060@ukr.net; ORCID ID: 0000-0001-9944-0476

\title{
СУГЕСТОЛОГІЯ ЯК ОДИН ІЗ МЕТОДІВ ВИВЧЕННЯ УКРАЇНСЬКОЇ МОВИ ЯК ІНОЗЕМНОЇ: ЩОДО ЗАСТОСУВАННЯ СУГЕСТОЛОГІЧНОГО МЕТОДУ Г. К. ЛОЗАНОВА
}

Анотація. Стаття актуалізує проблему вивчення української мови як іноземної та шляхи оптимізації цього процесу. Вивчення методів викладання іноземних мов дозволяє лінгвістам, оцінюючи переваги та недоліки кожного 3 них, використовувати найбільш зручну й ефективну основу для формування граматичної та лексичної бази з метою створення навчальних матеріалів. Сугестивний метод $\Gamma$. К. Лозанова дає змогу оптимізувати процес навчання у всіх аспектах. Основна теза цього методу - невимушена атмосфера під час занять, яка сприяє природному способу засвоєння матеріалу без особливих зусиль та примусу. Саме відсутність психологічного тиску на учня у форматі “вчительучень” звільняє додаткові запаси пам'яті. Мета дослідження - виявити сугестивні особливості вивчення української мови як іноземної, висвітлити сугестивний метод вивчення української мови як іноземної, а також спробувати реалізувати його відповідно до потреб курсу. Об'єктом вивчення є сугестивний підхід, а предметом - його впровадження в процес навчання. Серед методів дослідження при вивченні цієї теми можна виокремити аналіз визначень словникового запасу, описовий метод, метод інтерпретації з використанням прийомів спостереження й узагальнення. Результати теоретичного й експериментального дослідження доводять до висновку про можливість застосування у сучасному навчанні української мови як іноземної сугестологічного методу Г. К. Лозанова. Практична цінність роботи полягає в тому, що її матеріали та висновки можуть бути використані в процесі читання лекцій та проведення семінарів з курсів (Методи вивчення іноземних мов», “Українська мова як іноземна), у практиці вивчення української мови як іноземної.

Ключові слова: українська мова як іноземна, методи вивчення іноземних мов, сугестологічний метод Г. К. Лозанова, навчання, навіювання.

Постановка проблеми. Сьогодні велика кількість іноземних громадян здобуває освіту у різноманітних вищих навчальних закладах України. Опанування української мови як іноземної не є більше справою смаку - з 2019 року її вивчення регламентується Законом України, а курс “Українська мова як іноземна» викладається на підготовчих відділеннях багатьох факультетів і став обов'язковим. Актуальність теми зумовлена також підвищенням інтересу до вдосконалення методик вивчення української мови як іноземної, потребою не калькування наукової бази і практичних матеріалів, а розробляти власні, адаптовані під особливості української мови.

Термін і власне курс "українська мова як іноземна) виникає і набуває вжитку у II-ій половині ХX ст. [1], після отримання Україною незалежності, а розробка й унормування загальних рівнів володіння українською мовою за міжнародною шкалою здійснюється лише з 2010 -х років. Підготовчі факультети або відділення багатьох університетів мають власні напрацювання, методики і підручники з цього курсу, проте сугестивний метод репрезентований у них фрагментарно.

На сучасному етапі основною метою в навчанні української мови як іноземної є комунікативна необхідність, яка визначає увесь навчальний процес: вивчення засобів мовлення під час спілкування та цілеспрямованого вдосконалення усіх основних видів мовленнєвої діяльності: аудіювання, говоріння, читання і письма. 3 іншого боку, формування умінь і навичок користування мовою передбачає широке застосування інтерактивних методів навчання, оптимальне поєднання фронтальної, групової та індивідуальної форм організації навчального процесу. За такого підходу особливого значення набу- 
ває змістовий аспект мовлення, його вплив на партнера під час спілкування, реалізація всіх основних фрункцій спілкування (пізнавальної, цілісно-орієнтаційної, регулятивної і конвенційної) [1, с. 228].

Зв'язок із суміжними і попередніми дослідженнями. Сугестивний метод (сугестопедія, як називає сам Г. К. Лозанов [3; 4] як науковий напрям була розроблена болгарським лікарем-психотерапевтом, який у подальшому став і педагогом. Сам метод набув найбільшого розповсюдження у 6070-і pp. XX ст. Масові експерименти з навчання іноземної мови було розпочато в 1964 р. у Болгарії в Інституті спеціалізації й удосконалення лікарів у Софої. 31965 р. для досліджень у цій царині була створена наукова група в Науково-дослідному інституті педагогіки імені Тодора Самодумова в Сoфiї (з 1966 р. - Науково-дослідний інститут сугестології). У СРСР проблемами сугестопедії займався Московський інститут іноземних мов імені Моріса Тореза спільно з Московським державним педагогічним інститутом імені В. І. Леніна. Послідовниками Г. К. Лозанова в СРСР стали Л. Ш. Гегечкорі, Г. А. Китайгородська, А. А. Леонтьєв, Н. В. Смирнова, І. Ю. Шехтер, В. В. Петрусинський, а сам метод, який отримав первісну назву (лозанівський), потім був перейменований на експрес-метод, а пізніше - інтенсивний метод [2, с. 139]. Відомі також розробки Г. А. Гончарова, О. В. Герасимової, А. А. Плигіної, Т. Ю. Ковалевської, С. О. Ніколаєнко, С. С. Пальчевського, інших дослідників, проте на грунті української вони не об'єднані теоретичними підвалинами. В українському мовознавстві сугестологічні дослідження широко представлені в Одеській лінгвістичній школі, проте питання педагогіки висвітлені розрізнено.

Формулювання завдань. Стаття має описати результати нашого дослідження, які покликані накреслити магістральні лінії застосування сугестивного методу під час вивчення української мови як іноземної. Мета нашого дослідження - у розробці засад застосування сугестологічного методу вивчення української мови як іноземної. На цьому етапі поставлені такі завдання: визначити найпопулярніші методи вивчення української мови як іноземної, наявні в сучасному навчальному процесі; з'ясувати місце сугестивного методу серед них та спроєктувати подальші тенденції розвитку зазначеного методу. У статті запропоновано розширити методологічні підходи із урахуванням сучасних психологічних особливостей сприйняття інформації і власне процесу навчання [9], звернувши увагу на сугестивний метод навчання.

Практична цінність розробки полягатиме в тому, що їі результати можуть бути використані в теоретичному і практичному кластерах курсів методики вивчення іноземних мов, сугестології, курсу “Українська мова як іноземна), а також під час створення методистами підручників і навчальних посібників.

Виклад основного матеріалу. Серед панівних методів навчання української мови як іноземної можливо виокремити: прямий, перекладний, свідомо-практичний, комунікативний методи [1, с. 230$]$.

Одним із найбільш розповсюджених методів вивчення української мови як іноземної є прямий метод. За такого методу рідна мова вилучається із процесу навчання, основною метою стає оволодіння усним мовленням, а читання чи письмо розглядаються виключно як засоби навчання мовленню [1, с. 230]. Під час застосування прямого методу студенти імітують мовлення і будують нові речення за аналогією на базі запропонованих зразків. Доцільно наголосити на певних перевагах прямого методу: часовий чинник (висока концентрація навчальних годин, через що відбувається глибоке занурення в мовне середовище) із оптимальною є наповненістю групи від 5 до 8 осіб.

Щодо доцільності перекладного методу науковці [9] припускають можливість його використання на заняттях із певним обмеженнями, тому що, незважаючи на те, що окремі слова збігаються за значенням, постійний дослівний переклад породжує неправильні конструкціїу мові, яку вивчають. До того ж,процес перекладу є психологічно значно складнішим від аудіювання, читання чи письма, і становить собою окремий вид підготовки. Попри це, в сучасній методиці навчання мови як іноземної усталилася думка про необхідність повної відсутності перекладу рідною мовою чи зіставлення із нею [9, с. 153-154].

Застосування свідомого-практичного методу передбачає, з одного боку, забезпечення розуміння студентами мовного матеріалу, який вивчають, а з іншого - цільову установку на практичне оволодіння мовою. Т. Капітонова, Л. Московкін виокремлюють найважливіші особливості цього методу [9]: характер навчання принципово безперекладний, усне мовлення з дотриманням послідовності «слухання - говоріння - читання - письмо ", рекомендований час у такому співвідношенні, як: теоретичні пояснення (15\%) та інтенсивне заняття мовленнєвою практикою із використанням наочності (85\%).

Комунікативний метод є панівним у сучасній вітчизняній методологічній думці. Коли саме процес навчання є моделлю комунікації. Однак, комунікативність методу передбачає схожість процесів навчання і комунікації лише у поведінці викладача і студентів під час занять, а предметність процесу комунікації, зумовлена ретельним відбором мовленнєвих інтенцій, ситуацій спілкування, що відображають практичні інтереси і потреби студентів [9, с. 155].

На думку Г. К. Лозанова, особистість учня стала центральною фігурою процесу навчання. I саме від неї залежить процес будування структури подання матеріалу. За його твердженням, інформація ззовні може проникати у внутрішній світ особистості двома каналами: свідомим і несвідомим. Останній канал передбачає використання засобів активізації резервних психічних можливостей особистості в навчальному процесі, зокрема під час навчанні іноземних мов [3; 4, с. 55].

Такий підхід до навчання перебудовує систему мотивації і сам процес навчання, що призводить до його високої ефективності, яка полягає в її спрямованості на комплексний розвиток особистості 
учня, на одночасний прогрес інтелектуальних, емоційних і мотиваційних сторін. Реалізація установки на розкриття резервів особистості учня здійснюється за рахунок таких чинників [2, с. 138]:

- творча роль викладача i, як наслідок, його авторитет;

• високий емоційний тонус аудиторії і емоційна залученість у навчальний процес;

- високомотивована навчальна діяльність, спрямована на зміст навчання;

- гармонізація діяльності обох півкуль головного мозку шляхом фонового звучання музики;

- чергування темпів навчання, які створюють гіпнотичний еффект;

- особлива роль і місце особистості викладача у навчальному процесі;

- перемикання уваги і концентрації на власне змісті матеріалу, який вивчають та ін.

Експериментальні дані Б. Д. Кавасарського [5] на основі дослідження сугестології як методу навчання показують зростання ефективності засвоєння навчального матеріалу в 29 разів у порівнянні із класичними методами. Зросли такі показники, як: засвоєння значного шару лексичного корпусу мови; уміння гнучко варіювати і вживати відповідну лексику; створення надзвичайно потужної мотивації навчання; зняття психологічних бар'єрів (сорому, страху, скутості).

Із часом Лозанівський метод трансформувався в інтенсивний метод, який здійснив прорив у методиках вивчення іноземних мов, оскільки він відповідав основним очікуванням студентів: опанувати мову швидко, запам'ятати основний лексичний корпус без непереборних труднощів, говорити мовою без страху, невимушено.

Найбільш сучасний метод підходу до викладання - інтерактивний метод, який розвинувся на грунті лозанівського вчення, побудований на грі, взаємодії студента і викладача із основною увагою на студентах, а не викладачі.

Висновки. Отже, із накреслених напрямів розвитку практичного боку дисципліни «Українська мова як іноземна» можна зазначити, що існує кілька усталених методів: прямий, перекладний, свідомо-практичний і комунікативний. Сугестивний метод, або інтенсивний, представлений в українській традиції вивчення мови як іноземної дуже епізодично. Але саме він має значні перспективи розвитку на сучасному грунті і відповідає сучасним дидактичним вимогам.

\section{Лiтература}

1. Бакум 3. П. Українська мова як іноземна : лінгводидактичні проблеми. Філологічні студї̈. Кривий Ріг, 2010. Вип. 5. С. 226-232.

2. Курбакова М. А. Способы оптимизации процесса обучения иностранному языку (современное применение психотерапевтического метода доктора Лозанова). Язык и культура. Томск, 2016. № 3 (35). С. 137-145. DOI : $10.17223 / 19996195 / 35 / 12$.

3. Лозанов Г. К. Основы суггестологии. Проблемы на суггестологията. София : Editura Sciifica, 1973. С. 55-70.

4. Лозанов Г. К. Суггестология. София : Editura Sciifica, 1971. 245 с.

5. Кавасарский Б. Д. Психотерапевтическая энциклопедия. Санкт-Петербург : Питер, 2000. 563 с.

6. Китайгородская Г. А. Методика интенсивного обучения иностранным языкам : учеб. пособие для преподавателей вузов и студ. пед. ин-тов. Москва : Высш. шк., 1982. 141 с.

7. Текучев А. В. Методика русского языка в средней школе. Москва : Просвещение. 1970. 606 с.

8. Труба Г. М. Нейролінгвістичні дослідження у методиці викладання української мови як іноземної. Записки з українсъкого мовознавства. Одеса, 2019. Вип. 26. Т. 2. С. 336-340.

9. Щукин А. Н., Московкин Л. В. Хрестоматия по методике преподавания русского языка как иностранного. Москва : Русский язык, 2010. С. 132-133.

\section{References}

1. Bakum, Z. P. (2010), "The Ukrainian as a foreign language: linguodidactical problems", Philological studies ["Ukrayinska mova yak inozemna : lingvodydaktychni problem", Filolohichni studii], Krivyi Rig, vol. 5, pp. 226232.

2. Kurbakova, M. A. (2016), Ways to optimize the process of learning a foreign language (modern application of the psychotherapeutic method of Dr. Lozanov), Language and culture ["Sposoby' optimizatsii protsessa obucheniya inostrannomu yazyku (sovremennoe primenenie psikhoterapevticheskogo metoda doktora Lozanova)", Yazyk $i$ kultura], Tomsk State University Press, Tomsk, issue 3 (35), pp. 137-145. DOI : 10.17223/19996195/35/12.

3. Lozanov, G. K. (1973), "Fundamentals of suggestology", Problems on suggestology ["Osnovy' suggestologii", Problemy na suggestologiyata], Editura Sciifica, Sofia, pp. 55-70.

4. Lozanov, G. K. (1971), Suggestology, [Suggestologiya], Editura Sciifica, Sofia, 245 p.

5. Kavasarsky, B. D. (2000), Psychotherapeutic encyclopedia [Psikhoterapevticheskaya entsiklopediya], Piter, Sankt-Peterburg, 563 p.

6. Kitaygorodskaya, G. A. (1982), Methods of intensive training in foreign languages : textbook [Metodika intensivnogo obucheniya inostrannym yazykam : ucheb. posobie], Vysshaya shkola, Moscow, 141 p.

7. Tekuchev, A. V. (1970), Methods of the Russian language in high school [Metodika russkogo yazyka $v$ sredney shkole], Prosvechenie, Moscow, $606 \mathrm{p}$.

8. Truba, G. M. (2019), "Neurolinguistic research in the methodology of teaching Ukrainian as a foreign language", Opera in linguistic ukrainiana ["Neirolinhvistychni doslidzhennia u metodytsi vykladannia ukrainskoi movy yak inozemnoi", Zapysky z ukrainskoho movoznavstva], Odessa, issue 26, vol. 2, pp. 336-340. 
9. Shchukin, A. N. Moskovkin, L. V. (2010), Reader on the methods of teaching Russian as a foreign language [Khrestomatiya po metodike prepodavaniya russkogo yazyka kak inostrannogo], Russkiy yazyk, Moscow, pp. 132-133.

\section{Hanna M. TRUBA,}

Candidate of Philological Sciences, Associate Professor, Department of the Applied Linguistics, Odessa I. I. Mechnikov National University; 24/26 Francuzskiy blvd., Odessa, 65058, Ukraine; tel.: +38 0632366706 ; e-mail: 3182009060@ukr.net; ORCID ID: 0000-0001-9944-0476

\section{SUGESTOLOGY AS ONE OF THE METHODS OF STUDYING THE UKRAINIAN LANGUAGE AS A FOREIGN: REGARDING THE APPLICATION OF G. K. LOZANOV'S SUGESTOLOGICAL METHOD}

Summary. The article actualizes the problem of studying the Ukrainian languages a foreign language and the ways to optimize this process. This study of methods of teaching foreign languages allows linguists, evaluating the advantages and disadvantages of each methods, to use the most convenient and effective background for the formation of a grammatical and lexical basis for the creation of educational materials. G. K. Lozanov's suggestive method allows optimizing the learning process in all aspects. The main thesis of which is a relaxed atmosphere during class, which contributes to the natural way of assimilating the material without much effort and coercion. It is the absence of psychological pressure on the student in the "teacher-student" format that free sup additional memory reserves. The purpose of the article is not only to illuminate the suggestive method of studying the Ukrainian language as a foreign, but also to try to implement it according to the needs of the course. The object of the article is the studying of a suggestive approach, and the subject of research is the introduction of this method into the learning process. The relevance of the topic lies in the fact that the process of improving the methods of studying the Ukrainian language as a foreign language never stops, especially since it always requires more effective and more modern, the creation of more effective teaching materials. Among these search methods in the study of this topic, one can single out an analysis of vocabulary definitions, a descriptive method, an interpretation method using observation and generalization techniques. The practical value of the work lies in the fact that its results can be used in the course of lecturing and conducting seminars on the courses "Methods of Studying Foreign Languages", "Ukrainian as a Foreign Language", as well as in the practical study of Ukrainian as a foreign language.

Key words: Ukrainian as a foreign language, ignorantly didactic methods, G. K. Lozanov's suggestological method.

Статтю отримано 28.03.2021 p.

DOI: $10.18524 / 2307-4558.2021 .35 .237789$

UDC 81'322.2/.3’271.14/.16’367

\section{Olena POZHARYTSKA,}

candidate of Philological Sciences (PhD), Associate Professor at the Chair of English Grammar,

Odessa Mechnykov National University; 2 Dvoryanska street, Odessa, Ukraine, 65082; tel. +380509632062;

e-mail: grammarlena@onu.edu.ua; ORCID ID: 0000-0003-4820-8129

\section{Kyrylo TROITSKYI,}

undergraduate student at the faculty of Romance-Germanic Philology, Odessa Mechnykov National University; 2 Dvoryanska street, Odessa, Ukraine, 65082; tel. + 380986567113; e-mail: troickiykirill@gmail.com;

ORCID ID: 0000-0002-3395-2724

\section{DIGITAL TECHNOLOGIES FOR GRAMMATICAL ERROR CORRECTION: DEEP LEARNING METHODS \& SYNTACTIC N-GRAMS}

Summary. The object of this article is automated grammatical error detection as a field of linguistics. The subject of the article is the variety of methods and techniques used in grammatical error detection along with their applications and evaluation. The article considers the most productive methods used in the field of grammatical error detection and correction in computational linguistics. The purpose of the article is to review major rule-based and deep learning methods used in the area, evaluate and compare them. The methods of research used in this article are data analysis, description of abstract computational models and observation of their performance. The article offers and defines a model based on syntactic n-grams, describes the ways of its implementation and the necessary pre-processing steps for the model to work. The particular error types that the model is capable of detecting are noun-verb agreement errors, preposition errors, noun number errors and some article error types. Also, the article analyses a recent model based on the transformer architecture - GECToR (Grammatical Error Correction: Tag, Not Rewrite). This deep learning model is aimed at detecting and correcting much more complicated errors, including those that rely on extralinguistic realia. Additionally, it is very useful because in contrast to other models that just replace incorrect tokens without explanations, GECToR assigns labels that can be further interpreted for educational purposes. Also, conclusions were made about the advantages and disadvantages of the described models that were discovered after their practical implementation. 